\title{
Transport, ecology and taxes in the context of globalization
}

\author{
Nikolai Privalov \\ Emperor Alexander I St.Petersburg State transport University, Economics Department, \\ Moskovskij, 9, 190031, e-mail: Ns-privalov@mail.ru Saint Petersburg, Russia
}

\begin{abstract}
Research background: One of the global problems of modern transport is the harmful impact on the environment due to the use of carbon fuels. This is especially true in the context of the globalization of the economy and environmental problems. The world has long been in the process of switching to alternative energy sources and reducing the use of fossil fuels. Administrative measures and taxation of $\mathrm{CO}_{2}$ emissions are applied.
\end{abstract}

Purpose of the article:The purpose of the article is to conduct a literary review in peer-reviewed publications on the problem of transport taxes and to make proposals for the introduction of an environmental tax within the framework of the classification of taxes proposed by the author for the purpose of their introduction. This analysis showed the predominance of publications with an environmental aspect. Basically, the authors analyze the application of taxes on $\mathrm{CO} 2$ emissions, as well as various methods (logistical, technological, managerial) to reduce these emissions and improve the efficiency of transport systems. The main object of research is road transport, to a lesser extent - air transport and sea transport.

Methods: The system approach, methods of scientific abstraction, formal logic, dialectical-theoretical methods, the method of empirical analysis, and other economic methods were mainly used in obtaining research results.

Findings \& Value added: The article deals with the modern problems of calculating and paying the transport tax, its role in the costs of transport organizations. The transport tax in Russia is likely to be replaced by an environmental tax. The variants of introducing the "ecological" component in the transport tax used in Singapura are proposed. The classification of taxes proposed by the author for the purpose of their introduction can also serve the purpose of preserving the environment.

Keywords Economy; globalization; ecology; $\mathrm{CO} 2$ emissions; transport and environmental taxes

JEL Classification: Q580; H23; R490 


\section{Introduction}

This article examines the interweaving of several problems. The broadest of them concerns the essence of taxes. The question is what is a tax from a political and economic point of view - one-sided gratuitous payments in favor of the state, payment for state services or something else. The solution of more specific issues depends on this - first of all, the nature of the state's relations with its citizens (residents) and other market agents.

The second issue is the role of transport in the modern economy and, accordingly, the need and possibility of regulating its activities by the state. Taxes are the strongest economic regulator, so tax policy can either restrain or stimulate this most important area of the economy. Taxes can also produce a selective impact on the economy, stimulating some types of equipment and related infrastructure, or restraining other types of equipment and economic activity, if society requires it.

The third most important problem is ecology, which worsened in the second half of the twentieth century. And transport is the strongest factor of environmental pollution here, since most types of transport still run on fossil carbon fuels. National and international statistics have shown for more than half a century the increasing anthropogenic impact on the environment. Moreover, among all types of air and soil pollution, especially in cities, road transport stubbornly occupies the first place.

The fourth problem is the depletion of natural resources, especially fuel and energy, primarily related to the needs of transport infrastructure. The growing threat of a shortage of fossil fuels (primarily easily accessible oil reserves) increases the cost of searching, extracting, and processing fuel. This, in turn, aggravates international relations, making oil and gas issues an instrument of political struggle, generating not only trade wars, but also tough economic sanctions, lawsuits in international courts, military conflicts, information, diplomatic wars, etc.

Therefore, the promotion of any recommendations for state regulation of the transport system must inevitably proceed from taking into account all these factors.

Even Professor V. Yarotsky in 1896 - 1909, studying the theoretical foundations of taxation, the history of their appearance and scientific theories, concludes that there are two directions in scientific theoretical thought that consider taxes. However, the author does not name them.

Having studied them, we believe that the first concept should be called «absolute». The essence of this theory is that the state has an absolute right to demand taxes, and citizens have an absolute obligation to pay them. Therefore, taxes are understood, as compulsory fees levied by the state from legal entities and individuals to cover their expenses or to achieve certain economic goals, without providing payers with a special equivalent-services. Thus, taxes are assigned a sign of one-way movement of value - a sign of non-equivalence. There are quite a lot of supporters of this theory, for example: A. Trivus, A. Sokolov, B. G. Boldyrev, V. K. Babaev, A.V. Bryzgalin, L. A. Drobozina, N. I. Khimicheva, T. F. Yutkina, etc. (Privalov N.G. and Privalova S.G., 2011). This point of view was reflected and prevailed in the Russian tax legislation and scientific thought before the introduction of the Tax Code. 
Moreover, it should be noted, that it was the sign of "lack of equivalence" that distinguished the Russian school of economists on the essence of taxes from the global one. This feature of the positions of the majority of Russian economists, we believe, has a basis in a certain "mental" understanding of the tax: the creation of a single state "Russia" went a very long centripetal path, overcoming long periods of struggle for the creation of a single multinational state.

The "Theory of the social contract", on the contrary, believes that people have united in the state so that it takes over part of their concerns: services for defense, law enforcement, political structure, economic and social regulation, etc. These services are precisely those that the state provides to all members of its society, regardless of whether they are taxpayers or not. Therefore, it is hardly appropriate to talk about a one-way movement of value.

The second point of view, we believe, should be called «the relative theory». It boils down to the fact that the tax is a kind of price for the monopolistic purchase and sale of state services in the performance of its functions. At the same time, the seller is the state, and the buyer is the society represented by the subjects of taxation: enterprises, organizations and the population. In this market of services, the state acts as a monopolist, therefore, being interested in the maximum level of its income, it dictates its conditions in this kind of "market". Taxpayers, on the contrary, are interested in minimizing taxation.

There is a huge amount of information on the problem of ecology.

According to the materials of the magazine "New Scientist", researchers at the University of Southern Maine took samples of snow and soil on the top of the world -Everest. Snow samples were taken every 300 meters at altitudes from 5334 to 7772 meters. In all snow samples, a high content of arsenic and cadmium was recorded, which, according to the criteria of the US Environmental Protection Agency, cannot be called safe. Soil samples were also characterized by an increased content of arsenic.

In Russia, 75 million urban residents live in conditions of severe air pollution, and 10 million-in conditions when the permissible concentrations of harmful substances in the air are exceeded many times.

According to Italian scientist Vittorio Canuto, who worked for many years in the United States at the NASA Space Flight Center and teaches at Columbia University, ocean algae now absorb about $50 \%$ of the carbon dioxide emitted into the atmosphere in the form of industrial and automobile exhaust. However, this function weakens every year, as the water temperature increases and the metabolic processes slow down (Privalov N.G., 2012)

Almost a quarter of global greenhouse gas emissions come from the transport sector and about $30 \%$ from road freight transport.

The UN's efforts to combat climate change over the past 28 years have not been sufficiently successful. It is clear that the global average temperature is rising (1.1 degrees above the pre-industrial level in 2019). Of particular concern is the fact that the Paris Agreement to keep the global average temperature Rise below +2 degrees Celsius is not being implemented, as the world's focus is on the consequences rather than the causes (Glasnovic et al.,2020).

We note a number of publications devoted to environmental pollution as a result of the operation of vehicles (Pesotskaya et al.,2020). 
A number of articles are devoted to technological innovations: the impact of technological innovations on green growth in twenty-eight countries of the Organization for Economic Cooperation and Development (OECD) from 2000 to 2014; intensive use of energy-efficient technologies, especially in transport (Glasnovic et al.,2020); hydrogen production from hydroelectric power plants for the transport sector.

Often, the authors explore specific aspects of the problem or make their own original proposals, including: integrate a carbon tax on $\mathrm{CO}_{2}$ emissions into transport costs, link this tax to the production cycle to encourage wider adoption of biogas, reduce taxes on trucks using liquefied natural gas.

Part of the research is devoted to logistics in order to reduce the cost and total carbon emissions: it is proposed to implement container transport strategies; a logical integrated model of cargo transportation by cars, which allows to reduce the cost and emissions by an average of $5.6 \%$ and $14.42 \%$, respectively.

Part of the work is devoted to political aspects: administrative measures receive more public support than market-based ones.

Scenario study raising taxes on private vehicles, along with other measures applied to Indonesia, could improve the efficiency of transport systems and reduce traffic congestion by $80 \%$.

According to the model proposed for car rental in the Canary Islands, the tax is proposed to increase with the number of days of car rental, but to reduce in accordance with the environmental performance of the car.

A differentiated system of the kilometer tax on the use of roads for the purpose of noise compensation is proposed (Swardh and Genell,2020).

A study was conducted on the willingness of citizens to reduce the use of cars in the lowcarbon metropolis of Hangzhou, a study on the optimal level of transport taxes in the United States and the United Kingdom Великобритании (Hirte and Tscharaktschiew,2020).

Quite a lot of publications are devoted to the experience of introducing electric cars. The study examines the experience of Norway, which has the highest share of electric vehicles in the world in its passenger car fleet due to the policy of high taxes on the purchase of traditional cars, the absence of tolls, VAT and free parking of electric vehicles. To reduce the cost of operating electric vehicles, a very important aspect is the introduction of taxes on $\mathrm{CO}_{2}$-based fuels (Ajanovic and Haas,2020). The results of the study of the electric car market in India show that a combination of subsidies and a green tax can provide higher social welfare compared to using only one of them in both the monopoly and duopoly markets (Chakraborty et al.,2020).

The aviation sector is also being studied. The US aviation fuel tax cut to support airlines in the face of the COVID-19 pandemic increases air traffic by an average of $0.2 \%$, but disappears within a year, with more than $1 \%$ increase in $\mathrm{CO}_{2}, \mathrm{CH}_{4}$ and $\mathrm{N}_{2} \mathrm{O}$ emissions (Sobieralski and Hubbard). The climate tax, which will be applied in the aviation sector, will also be able to provide important steps in the fight against climate change (Akdemir,2020). The problem of the policy of stimulating the carbon tax on air passenger transport is investigated (Qiu,2020). 
It is proposed to establish individual tax regimes that seaports should develop and implement independently (Belyaev et al.,2020).

The social consequences of environmental policies are investigated: the effects on different groups of households when introducing a carbon tax on transport in Germany (Eisenmann et al.,2020), Spain (Savin et al.); how the pre-tax and post-tax share of rich and poor households affects the purchase and operation of personal vehicles in 14 OECD countries for the period 1992-2016 (Valenzuela-Levi,2021); a calculation of the possible negative cost effects of environmental taxes is made - a drop in employment and an increase in poverty in Chile (Mardones and Mena,2020), an alternative system of environmental taxation is proposed, aimed at stimulating the transition to socio-environmental sustainability without a negative impact on poor households (Gazzani,2021); it is revealed that the vehicle tax in Poland is an important tax in terms of tax benefits that reduce the tax burden (Furman,2020).

The introduction of an environmental tax in China does not affect the balance of transportation volumes, ticket prices, consumer welfare and social security in a high-speed railway company when competing with an airline (Xu et al.,2020).

The results of the study show that the increase in carbon taxes affects consumer behavior, causing a significant shift from gasoline to diesel fuel of vehicles (Nadirov et al.,2020).

Russian authors publish quite a lot of articles about the connection of transport with ecology, in particular, on the problems of disposal of harmful substances or industrial waste as part of building materials while simultaneously protecting the soil and, in general, the ecosystem in transport construction (Shershneva et al.,2020). Therefore, to fulfill the purpose of the study, it is necessary to link the problems of transport, ecology and taxes, taking into account the Russian situation.

The problem of limited resources, primarily natural ones, became particularly acute in the second half of the twentieth century, when the rapidly growing population of the Earth began to consume them more and more.

The most famous project that began serious scientific research in this direction were the models of D. Forrester and D. Meadows. In 1970, a scientist at the Massachusetts Institute of Technology, Jay Forrester, based on the methodology of system dynamics created by him, developed the first computer-based global models of world development "World-1" and "World-2". A group of his students led by Dennis Meadows in 1972 analyzed the relationship of variables in the "World-3" model: industrial production, population, food production, natural resources, environmental pollution, life expectancy, consumption of goods, food, services per capita.

The authors of the project primarily proceeded from the estimated volume of mineral resources available in the world for 1970. Thus, according to the US Bureau of Mining, at the then existing rates of aluminum consumption, there were 100 years of production in the world, cobalt-by 110 , copper-by 36 , gold-by 11 , iron-by 240 , lead-by 26 , manganese-by 97 , mercury-by 13 , natural gas-by 38 , oil-by 31 , silver-by 16 , tin-by 17 years, tungsten-by 40 , zinc-by 23 , nickel-by 150 , etc. However, if we take into account that the rate of resource consumption accelerates and after a certain period of time there is a doubling of consumption, i.e. there is an exponential growth, then the known resources can run out much faster. For example, aluminum reserves will be depleted not in 100, but in 31 years. If we assume that 
only a fifth of the world's aluminum ore reserves have been explored so far, then it should still end by 2022 .

The main result of their project, carried out on the instructions of the "Club of Rome", is the conclusion that if the consumption of material resources remains unchanged, the collapse of production and a sharp decline in material standards of living will occur around 20302050. Thus, by 2000 , the number of the world's population was expected to be $6-7$ billion people, by $2050-10.9$ billion. Therefore, by 2050 , the production of food products per capita should fall to the level of 1900 , the production of industrial products per capita - to the level of 1928, and the similar production of services - to the level of 1958.

The population, according to the model, which provides for a fourfold lower rate of expenditure of resources than it actually happened in 1970, reaches its maximum number in 2030 , and then falls sharply to one-sixth of this maximum value over a 20 -year period (Ferrester,1978).

\section{Research methodology}

In obtaining the research results, we mainly used a systematic approach, methods of scientific abstraction, formal logic, dialectical-theoretical methods, the method of empirical analysis, and other economic methods.

\section{Research results}

The question of the essence of taxes in relation to Russia should be solved specificallyhistorically. Centuries ago, during the formation and strengthening of a centralized monarchical state, taxes were essentially unilaterally directed non-equivalent payments. However, in modern Russia, in connection with the formation of the democratic foundations of society, it makes sense to turn to the theory where taxes are a quasi-payment for the provision of services by the state. This will manifest the formation of the modern principle of formal legal equality of the state and citizens.

The solution of environmental problems is possible not by taking individual private measures of a nature protection nature, but as an integral system for restoring the balance of man and society with nature. At the same time, this should also serve as a solution to the problem of the growing shortage of natural resources, since the new, ecologized ideology of life implies not only an absolute reduction in the consumption of primary natural resources, but also a more comprehensive processing of raw materials based on technical achievements, its economy, replacement with alternative materials while forming an "ecological consciousness" and tightening the requirements of environmental legislation.

An obligatory element in modern conditions is energy saving and reducing the loss of heat, water, and other resources. A powerful impetus to the Western world in this direction was given by the energy crises of 1973, 1979 and 1980, when oil prices increased 20 times. After that, heat visors, water meters, energy-saving materials, etc. appeared. Since the beginning of the 90s, energy-saving programs have been launched in Russia on the initiative of the TACIS organization. There are a lot of new heat-insulating materials, heat-saving door and window blocks, stainless copper and plastic pipes, energy-saving electric lamps, etc.

An important direction is the more efficient use of traditional types and the development of non-traditional types of energy. An example is the replacement of fuel created on the basis of oil or coal with natural gas. 
When burning natural gas, emissions of harmful substances into the atmosphere are reduced by 10 times compared to coal and operations related to fuel preparation, ash removal and storage are completely eliminated. When using gas as a motor fuel instead of gasoline, emissions of carbon oxides are reduced by 5-6 times, nitrogen oxides by 1.5-2.5 times, hydrocarbons by 3 times, and polycyclic aromatic hydrocarbons by almost 10 times.

Doctor of Geological and Mineralogical Sciences V. Larin put forward a metal hydride hypothesis about the probable formation of oil as a result of the interaction of hydrogen and the upper layers of the Earth's crust. When carbon deposits get in the way, hydrogen turns them into a different type of hydrocarbon fuel: shale, coal turns into methane, oil or gas. The Staro-Grozny deposits were fully selected in the early 90s. The wells were damped, but already in 2006, oil leaked to the surface. Studies have shown that the deposits have been completely replenished. And such phenomena are no longer exotic, but a regularity .

An important issue is the creation of effective biofuels from various organic substances - manure, sewage, straw, grain, corn, etc. Perhaps the main ones here are the lack of production efficiency, and the advantages are the associated solution of environmental problems.

For the operation of a hydrogen engine, only oxygen and hydrogen are needed. There is water vapor on the exhaust from the pipe of such a car. The problem is where to get free inexpensive hydrogen. Just splitting water into oxygen and hydrogen, and then burning them is unprofitable. V. Larin hypothesized the presence of hydrogen deposits at a depth of 3-4 $\mathrm{km}$ in certain territories of the Earth, for example, in Transbaikalia. If this is the case, then it will be possible to extract it as an ordinary gas.

One of the economic tools for solving these problems is the development of the issue of transport taxes.

In the scientific literature for several years there have been discussions about the improvement of the transport tax: this problem causes discussions at the level of the Government of the Russian Federation and in the scientific literature. In official sources, there is a discussion that it is possible to cancel the transport tax. The cancellation of the tax itself was discussed, while the budget revenues will be compensated for by increasing the excise tax rates on motor fuel. Many economists, including officials dealing with tax policy issues in the country, believe that in the future it is inevitable to replace the transport tax with an environmental one (Privalov and Privalova,2013; Tax Code of the Russian Federation).

The role of the transport tax for transport organizations. Having considered the dynamics of transport tax revenues to the budget system of the Russian Federation, it is possible to see an increase in both the total amount of tax revenues and transport tax in particular.

The analysis shows that property taxes (transport tax and corporate property tax) are more significant for organizations of the transport industry: their share is 2-3 times more than in the general aggregate of organizations (in 2014, $14.16 \%$ of the corporate property tax for the transport industry against $5.03 \%$ for all enterprises and organizations, and in 2015 - already $15.03 \%$ against $5.2 \%$ ) and for transport tax: in 2014, 2.0\% for the transport industry against $0.93 \%$ for the entire aggregate enterprises and organizations in Russia. In 2015, this trend continued: $2.18 \%$ against $0.97 \%$ for the transport tax. This says: both about the capital intensity of the transport industry, and determines its dependence (depending on the size of its costs) from taxation of the property at its disposal, including - from the transport tax.

\section{Transport tax in the Russian Federation.}


Taxpayers. The transport tax belongs to the category of regional taxes. It was introduced on 01.01.2003 (Tax Code of the Russian Federation, ch. 28). Before that, in Russia, vehicles were included in the object of taxation of two types of property taxes with annual payment terms: a) the tax on the owners of vehicles; b) the tax on the property of individuals. Moreover, the tax on vehicle owners had a strictly targeted purpose and was credited to the territorial road funds.

In accordance with the Tax Code of the Russian Federation (Tax Code of the Russian Federation, Article 357), taxpayers are persons in whose name, in accordance with the legislation of the Russian Federation, vehicles that are recognized as an object of taxation are registered. Moreover, the structure of the object of taxation (Tax Code of the Russian Federation, Article 358) includes, in particular, the following types of registered vehicles: cars, motorcycles, scooters, buses, other self-propelled machines and mechanisms with pneumatic running, airplanes, helicopters, motor ships, yachts, sailing ships, boats, snowmobiles, motor sleds, motor boats, jet skis and other water and air vehicles.

Certain types of vehicles, due to their low capacity or the special nature of their operational purpose, are not recognized as objects of taxation (Tax Code of the Russian Federation, Article 358). These include, for example:

a) rowing boats, as well as motor boats with an engine power of no more than $5 \mathrm{hp}$;

b) passenger cars with an engine power of up to $100 \mathrm{hp}$, obtained through social protection agencies, and passenger cars specially equipped for the disabled;

c) commercial sea and river vessels; ... and also-vessels registered in the Russian International Register of Vessels.

Tax base and rates. The tax is paid by the owners of cars and other vehicles that are equipped with an engine. The calculation is taken from each horsepower. To correctly calculate the amount of tax, you need the following information:

a) since the tax is regional, the amount of the tax rate is set for each subject of the Russian Federation (i.e., the maximum tax rates are set by the Tax Code of the Russian Federation (Tax Code of the Russian Federation, Article 361), and the legislative authorities of the subjects of the Russian Federation have the right to increase or decrease them, but not more than 5 times Tax Code of the Russian Federation, Article 361 p.2) and establish differentiated tax rates for each category of vehicles, as well as taking into account their useful life (Tax Code of the Russian Federation, Article 361, paragraph 3);

b) the size depends on the engine capacity, year of manufacture and / or environmental class. Tax Base (NB): The NB is used as the horsepower of vehicles that have engines. This indicator is specified in the vehicle's technical data sheet or license plate.

The vehicle tax rates are a fixed monetary amount per unit of measurement of the tax base, i.e., per horsepower, kilogram of traction, register ton of gross tonnage, unit of vehicle.

The next indicator on which the tax depends is the number of months of ownership of the vehicle. For example, if the car was purchased on March 9 and sold on May 14, the ownership period is three months. An increasing coefficient can also be used.

The increasing coefficient. It applies to cars that cost more than 3 million rubles. 
Tax amount $=($ Tax rate $) \times(\mathrm{L} / \mathrm{s}) \times($ Number of months of ownership / 12) $\times$ (Increasing coefficient (if any))

The full formula for calculating the transport tax is shown above. The law provides for the establishment of differentiated rates for each category of vehicles, also depending on the number of years from the year of production of the vehicle, and (or) the environmental class.

The problem and its possible solutions. As can be seen from the table, the Russian Government is trying to solve the problem of ecology. However, firstly, such an increase is only passed on to the owners of expensive cars, and secondly, such a "tax for environmental degradation" is levied indirectly: depending on the power of the vehicle. The greater the capacity, the higher the tax rate.

As a rule, the newer the year of production of the vehicle, the less damage to the environment it causes. However, the increasing coefficients do not reflect this circumstance.

It should be noted that the rates of transport tax for individuals and for legal entities in the same region are equal. Since this tax belongs to the regional category, the rates may vary by region. The value of the rates is determined by the subjects of the Russian Federation (Tax Code of the Russian Federation, Article 361), but the state has set a limit. Regional rates can be no more than 10 times higher or lower than the limit.

As already mentioned above, the share of the transport tax in the total tax revenues to the budget of the Russian Federation is insignificant. As of 01.01.2016, it amounted to 1\% $(132,417,288$ thousand rubles). of all receipts; as of 01.01 .2015 , it was $1 \%$ (117 494089 thousand rubles). from all receipts (according to form No. 1-NOM). However, for transport enterprises, deductions to the budget for transport tax are significant.

According to the Federal Tax Service, as of 01.01.2016, the amount of tax transferred by organizations engaged in transport activities is $12,477,817$ thousand rubles, which is $9 \%$ of the amount for all industries. As of 01.01.2015, 11125943 thousand rubles, which amounted to $9.5 \%$. Thus, the reform of the transport tax will primarily affect transport organizations and their costs.

Thus, it can be stated that the improvement of the transport tax consists in the adjustment of the tax base: the tax is supposed to be abolished and replaced by an environmental one.

Foreign experience in solving the problem of "environmental friendliness" of transport equipment. There is an environmental tax throughout Europe, and the EU takes both excise taxes and «an environmental tax». In the tax systems of European and developed Asian countries, increasing and decreasing coefficients are mentioned, which can be used to take into account the age of the car and the environmental class of the engine.

Let's turn to the practice of protecting the environment from transport pollution in Singapore. The Government of Singapore is constantly investing in the development of public transport, as well as reducing the number of permits for the purchase of new cars (Certificate of Entitlement-a program of permits to reduce the number of private cars in the country). This is done to reduce car sales and, thus, reduce the degree of environmental pollution, as the purchasing power of Singapore's citizens is growing in a successfully developing economy. The Government of the country wants to make public transport a priority means of 
transportation for residents. At the moment, it is successfully doing this: only about $15 \%$ of residents own their own car.

When purchasing a vehicle in Singapore, you must pay the excise tax, as well as the registration fee, which is $150 \%$ of the market value of the vehicle. In addition, buyers need to place an application for the above-mentioned SOE, allowing you to use the car for 10 years.

Of course, Russia has no goal to adopt the concept of a transport tax from Singapore. The development and economy of these countries are completely different. Also, a significant reduction in the number of private cars in Russia at the moment is not possible and appropriate. Therefore, I would like to consider only some aspects of the transport tax in Singapore, which are directly related to the environment.

1. The additional fee paid at the time of vehicle registration (ARF) depends on the year of receipt of the SOE:

a) $130 \%$ of the market value for vehicles with COE issued from May 2002 to February 2004;

b) $110 \%$ of the market value for vehicles with COE issued from March 2004 to February 2008;

c) $100 \%$ of the market value for vehicles with COE issued since March 2008 .

Singapore's National Environmental Protection Agency has developed a scheme under which eco-car owners can receive benefits.

2. Singapore is allowed to import cars that have been used for no more than 3 years. Also, used cars must be charged an amount of 10,000 SGD.

3. The country has developed a strict scheme for limiting $\mathrm{CO} 2$ emissions for cars. For example, for vehicles with a low level of $\mathrm{CO}_{2}$ emissions, the application of tax incentives for the additional registration fee (ARF) is provided. For vehicles with a high level of $\mathrm{CO}_{2}$ emissions, the corresponding contribution is established.

Since January 1, 2013, the $\mathrm{CO}_{2}$ emissions scheme has been applied to both new and refurbished vehicles registered in Singapore.

4. Benefits for the Additional Registration Fee (ARF). The benefits can be applied to the ARF when the car is removed from the register, provided that the car is not older than 10 years. The benefits are calculated based on the date of de-registration after the date of the first registration of the car (the age of the car) (Shmonina,2015)

To what has been said, we can add our proposal to classify taxes in Russia according to the purpose of their introduction, i.e. to make all taxes targeted. This should strengthen the motivation to pay taxes (Privalov and Privalova,2011). One of such taxes should be environmental, which serves the cause of environmental protection (Privalov, 2010). 


\section{Conclusion}

Thus, we come to the following conclusions.

Within the framework of this study, the following tasks were solved:

a review of literary sources on the issue of the essence of taxes is carried out; a review of the literature sources on the topic of the study and an analysis of data on transport taxation in the Russian Federation and in Singapore; the impact of the transport tax on the state of the environment has been assessed; considered the problems of transport taxation in Russia are considered

- Possible ways of improving the transport tax are proposed, including the foreign experience-on the example of transport taxation in Singapore, affecting the environment, which can be partially applied in Russia.

- To the above, we can add our proposal to classify taxes in Russia according to the purpose of their introduction, i.e. to make all taxes targeted. This should strengthen the motivation to pay taxes. One of these taxes should be environmental.

- The introduction of targeted taxes should increase the motivation to pay them.

The transport tax in Russia is relatively new and will certainly continue to undergo changes. The protection of the environment through a transport tax is possible and even necessary. However, it should be taken into account that among legal entities, the main payers of transport tax are transport organizations. When re-forming transport taxation, it is necessary to ensure that the tax burden for these organizations is feasible and does not hinder the development of business.

\section{References}

1. Privalov N.G., Privalova S.G Tax system: theoretical and methodological aspect. Tax product (monograph). Yekaterinburg: Ural Publishing House, 2011

2. Privalov N.G. The Third Way of Russia: a new hope in the XX1 century (monograph). Yekaterinburg: Ural Publishing House, 2012

3. Glasnovic Z., Margeta K ., Logar N.Z. Humanity Can Still Stop Climate Change by Implementing a New International Climate Agreement and Applying Radical New Technology. Energies. Vol.13. Release. 24. (Dec, 2020) DOI: 10.3390/en13246703

4. Pesotskaya, E., Selyutina, L., Chernykh, A. Modern aspects of the formation and implementation of environmental policy in an urban conditions (2020) IOP Conference Series: Materials Science and Engineering, 880 (1), статья № 012069. DOI: 10.1088/1757899X/880/1/012069.

5. Swardh Jan-Erik, Genell A. Marginal costs of road noise: Estimation, differentiation and policy implications. Transport policy. Vol. 88. (Mar, 2020) DOI: 10.1016/j.tranpol.2020.01.009

6. Hirte G., Tscharaktschiew S. The role of labor-supply margins in shaping optimal transport taxes. Economics of transportation. Vol. 22. (Jun, 2020) DOI: $10.1016 /$ j.ecotra.2020.100156

7. Ajanovic A., Haas R. On the economics and the future prospects of battery electric vehicles. Greenhouse gases-science and technology. Vol. 10. Release 6. (Dec, 2020) DOI: 10.1002 /ghg. 1985

8. Chakraborty A., Kumar R. R., Bhaskar, K. A game-theoretic approach for electric vehicle adoption and policy decisions under different market structures. Journal of the operational research society. (Jan, 2020) DOI: 10.1080/01605682.2019.1678407 
9. Sobieralski J. B., Hubbard S. M. The Effect of Jet Fuel Tax Changes on Air transport, Employment, and the Environment in the US. Sustainability. Vol. 12. Release 8. DOI: $10.3390 /$ su12083352

10. Akdemir T. Aviation Taxes in European Union to Fight Against Climate Change. Ankara avrupa calismalari dergisi-Ankara review European studies. Vol. 19. Release 1. (2020)

11. Qiu R., Xu J., Xie H., Zeng Z., Lv Ch. Carbon tax incentive policy towards air passenger transport carbon emissions reduction. Transportation research part D-transport and environment. Vol. 85. (Aug, 2020) DOI: 10.1016/j.trd.2020.102441

12. Belyaev S. G.' Dorogov N. I., Kapitonov I. A., Asabina S. N. Ensuring competition in the context of globalization of maritime transport services. Entrepreneurship and sustainability issues. Vol. 7. Release 3. DOI: 10.9770/jesi.2020.7.3(12)

13. Eisenmann C., Steck F., Hedemann L., Lenz B., Koller F. Distributional effects of carbon taxation in passenger transport with lump-sum offset: low income households, retirees and families would benefit in Germany. European transport research review. Vol. 12. Release 1. (Sep 21, 2020) DOI: 10.1186/s12544-020-00442-6

14. Savin I., Drews S., Maestre-Andres S., van den Bergh J. Public views on carbon taxation and its fairness: a computational-linguistics analysis. Climatic change. Vol. 162. Release 4. DOI: 10.1007/s10584-020-02842-y

15. Valenzuela-Levi N. The rich and mobility: A new look into the impacts of income inequality on household transport expenditures. Transport policy. Vol. 100. (Jan, 2021) DOI: 10.1016/j.tranpol.2020.10.002

16. Mardones C., Mena C. Effects of the internalization of the social cost of global and local air pollutants in Chile. Energy policy. Vol. 147. (Dec, 2020) DOI: 10.1016/j.enpol.2020.111875

17. Gazzani F. Transition to social-ecological sustainability using the environmental fiscal reform. International Journal of social economics. (Feb, 2021) DOI: 10.1108/IJSE-092020-0656

18. Furman L. Preferences in Local Taxes in Poland. Hradec Economic days 2020, Vol. 10, PT 1 DOI: 10.36689/uhk/hed/2020-01-019

19. Xu L., Fan X., Luan W. Strategic corporate social responsibility of high-speed rail in China. China economic review. Vol. $62 . \quad$ (Aug, 2020) DOI: $10.1016 /$ j.chieco.2020.101499

20. Nadirov O., Vychytilova J., Dehning B. Carbon Taxes and the Composition of New Passenger Car Sales in Europe. Energies. Vol.13. Release 18. (Sep, 2020) DOI: 10.3390/en13184631

21. Shershneva M., Sakharova A., Anpilov D., Eremeev E. Efficiency evaluation of the use of mineral technogenic substances in geoecoprotective technologies of transport construction. Lecture Notes in Civil Engineering, 2020, 50, pp. 357-367. DOI: 10.1007/978-981-15-0454-9_37

22. Ferrester Dzh. Global dynamics.-Moscow: Nauka, the Main Editorial Office of the Physics and Mathematics Literature, 1978.

23. Privalov N.G., Privalova S.G. Moral Economics: Necessity and basic principles. Chapter in the monograph. -M.; There-bov:Publishing House of TSU named after G.R. Derzhavin, 2013. (The series "University scientific schools". Issue 8). pp.347-349

24. Tax Code of the Russian Federation (Part 2) dated 05.08.2000 No. 117-FZ (as amended on 03.07.2016)

25. Shmonina I.P. Options for reforming the transport tax in the Russian Federation and assessing their impact on the tax burden of the enterprise//Contentus.2015. pp.204-211 